\title{
Under the Veil of Science Fiction: Katniss’ Initiation in the Hunger Games Trilogy
}

\author{
YANG Chun \\ China Youth University of Political Studies, Beijing, China
}

\begin{abstract}
The success of the Hunger Games trilogy to the young readers is its distinctive blending of science fiction elements with protagonist Katniss' initiation. The trilogy suffices youth's interest to embrace a fiction that dramatizes both realistic and fantastic portray of the world. Through depicting the intellectual and social development of protagonist Katniss who, after experiencing both defeats and triumphs in a dystopian world, Suzanne Collins successfully conveys the coming-of-age theme under the veil of science fiction in the Hunger Games trilogy.

Keywords: the Hunger Games trilogy, science fiction, initiation, coming-of-age theme
\end{abstract}

\section{Introduction}

The Hunger Games trilogy is a young-adult science fiction series written by American author Suzanne Collins. It consists of three separately released novels, namely The Hunger Games (2008), Catching Fire (2009) and Mockingjay (2010). Since its publication, the trilogy was well received. On August 17, 2012, Amazon announced the Hunger Games trilogy as its top seller, surpassing the record previously held by the Harry Potter series. As of 2014, the trilogy has sold more than 65 million copies in the US alone and has been sold into 56 territories in 51 languages. It also has been on the New York Times best-seller list of children's series for 161 weeks (Hubler, 2014, p. 23).

The trilogy is set in a dystopian world of "Panem", a country consisting of the wealthy Capitol and 12 districts in varying states of poverty. Every year, 24 children between the ages of 12 and 18 from the poor districts are selected to participate in a compulsory annual televised death match called "The Hunger Games". The participants in the games are called "tributes" and are forced to fight to the death in a dangerous public arena. The purpose of the "Hunger Games" is to provide entertainment for the Capitol and to serve as a punishment to the Districts for the past rebellion against the Capitol as well as the reminder to the Districts of the Capitol's absolute authority and power.

Katniss Everdeen, the protagonist in the trilogy is a strong-willed 16-year-old girl from District 12. For the sake of protecting her sister Primrose from danger, she volunteers as a "tribute" in the games. In the trilogy, during her struggle for survival, Katniss not only bravely wins the games but also inspires rebellion in the districts against the Capitol. After going through many dangers and difficulties, Katniss becomes mature and grows up as a fighter against the tyranny and finally lives happily with her sweetheart Peeta Mellark.

YANG Chun, associate professor, M.A., Foreign Language Department, China Youth University of Political Studies. 
In the trilogy, Katniss, a young, frustrated, and immature protagonist is frequently confronted by a series of tests of death, struggles with them, learns something about the nature of good and evil in the world, and becomes a more mature and more humane human being. Based on a close reading of the text, the present paper aims at exploring the moral and social growth of Katniss in the Hunger Games trilogy under the veil of science fiction so as to interpret the coming-of-age theme in the novel.

\section{Under the Veil of Science Fiction}

According to Wikipedia (2016), the free encyclopedia, science fiction is a genre of speculative fiction dealing with imaginative concepts such as futuristic settings, futuristic science and technology, space travel, time travel, faster than light travel, parallel universes, and extraterrestrial life. Science fiction elements include:

(1) A time setting in the future, in alternative time lines, or in a historical past that contradicts known facts of history or the archaeological record;

(2) A spatial setting or scenes in outer space (e.g., spaceflight), on other worlds, or on subterranean earth;

(3) Characters that include aliens, mutants, androids, or humanoid robots and other types of characters arising from a future human evolution;

(4) Futuristic or plausible technology such as ray guns, teleportation machines, and humanoid computers;

(5) Scientific principles that are new or that contradict accepted physical laws, for example time travel, wormholes, or faster-than-light travel or communication;

(6) New and different political or social systems, e.g., dystopian, post-scarcity, or post-apocalyptic;

(7) Paranormal abilities such as mind control, telepathy, telekinesis (i.e., "The Force” in Star Wars), and teleportation;

(8) Other universes or dimensions and travel between them.

As young-adult science fiction novel, first the Hunger Games trilogy takes place in an unspecified future time in a dystopian world. The term "dystopia" evolved from the title of the novel Utopia by Sir Thomas More, written in 1516 ("Utopia”). That text postulated a world where everything was perfect. Dystopias, then, are the opposite: They are worlds where everything is imperfect. Situated in the genre of science fiction, they are generally set in the future, incorporating many recognizable elements of the present. They are characterized by a ruthless, autocratic government that oppresses its people and renders them powerless, either through fear or through technology, under the guise of creating a safe and orderly world (Sprague, 2016, pp. 23-24).

The Hunger Games trilogy is set in Panem, a fictional country created by Suzanne Collins where people live under economic inequality, totalitarian rule, and oppression maintained by brute force from the Capitol. Panem, "the country that rose up out of the ashes of a place that was once called North America” (Collins, 2008, p. 18) Panem, "a shining Capitol ringed by thirteen districts” (Collins, 2008, p. 18) survives from the Dark Days, the uprising of the districts against the Capitol. As the yearly reminder that the Dark Days must never be repeated, there is the Hunger Games.

The rules of the Hunger Games are simple. In punishment for the uprising, each of the twelve districts must provide one girl and one boy, called tributes, to participate. The twenty-four tributes will be poisoned in a vast outdoor arena that could hold anything from a burning desert to a frozen wasteland. Over a period of several weeks, the competitors must fight to the death. The last tribute standing win. ...To make it humiliating as well as torturous, the Capitol requires us to treat the Hunger Games as a festivity, a sporting event pitting every district against the other. The last tribute alive 
receives a life of ease back home, and their district will be showed with prize, largely consisting of food. All year, the Capitol will show the winning district gifts of grain and oil and even delicacies like sugar while the rest of us battle starvation. (Collins, 2008, pp. 18-19)

Against all odds, Katniss has won the Hunger Games. Both she and Peeta are miraculously alive. In Catching Fire, the second novel of the Hunger Games trilogy, as winners in the Hunger Games, Katniss and Peeta are on the Victor Tour. From narrator Katniss's point of view, readers can sense the horror and brutality of the Victor Tour and catch a glimpse of the totalitarian rule of the Capitol:

Strategically placed almost midway between the annual Games, it is the Capitol's way of keeping the horror fresh and immediate. Not only are we in the districts forced to remember the iron grip of the Capitol's power each year, we are forced to celebrate it. And this year, I am one of the stars of the show. I will have to travel from district to district, to stand before the cheering crowds who secretly loathe me, to look down into the faces of the families whose children I have killed... (Collins, 2009, p. 4)

Besides, as science fiction novel, the Hunger Games trilogy abounds with alien monsters, unexplained and unexplainable technology, and supernatural forces which are frequently seen in science fiction. "Muttation" designed by Gamemakers is one of the alien monsters.

Muttations. No question about it. I've never seen these mutts, but they're no natural-born animals. They resemble huge wolves, but what wolf lands and then balances easily on its hind legs? What wolf waves the rest of the pack forward with its front paw as though it had a wrist? These things I can see at a distance. Up close, I'm sure their more menacing attributes will be revealed. ...and in that moment I realize what else unsettled me about the mutts. The green eyes glowering at me are unlike any dog or wolf, any canine I've ever seen. They are unmistakably human. And that revelation has barely registered when I noticed the collar with the number 1 inlaid with jewels and the whole horrible thing hits me. The blonde hair, the green eyes, the number...it’s Glimmer. (Collins, 2008, pp. 331-333)

In Mockingjay, the third novel of the Hunger Games trilogy,during the battle against the Capitol, Katniss and her friends encounter numerous unexplained devastating forces:

Finick’s yelling something back, gesturing to the end of the block where er entered. Black, oily matter spouts like a geyser from the street, billowing between the buildings, creating an impenetrable wall of darkness. It seems to be neither liquid nor gas, mechanical nor natural, Surely it’s lethal, There’s no heading back the way we came.

Deafening gunfire as Gale and Leeg, I begin to blast a path across the stones toward the far end of the block. I don't know what they're doing until another bomb, ten yards away, detonates, opening a hole in the street. Then I realize this is a rudimentary attempt at minesweeping. Homes and I latch on to Boggs and begin to drag him after Gale. Agony takes over and he's crying out in pain and I want to stop, to find a better way, but the blackness is rising above the buildings, swelling, rolling at us like a wave. (Collins, 2010, pp. 278-279)

The dystopian and science fiction color of the Hunger Games trilogy on the one hand contribute to the success of the novel since they echo for young readers real issues that are current and pervasive. As Bullen and Parsons note, the dystopian novel, while purporting to be about the future, is actually a cautionary tale rooted in the practices of the present society (Sprague, 2016, p. 25). Contemporary teens are aware of uncertainties, risk, and evils around them and they look to dystopias as vehicles to both understand the risk and for ways to navigate the risk. On the other hand, the dystopian and science fiction color of the Hunger Games trilogy highlight the twists and turns of Katniss' initiation. 


\section{Katniss’ Initiation}

A novel that contains the initiation of the protagonist is generally referred to as a bildungsroman. In Season of Youth: The Bildungsroman From Dickens to Golding, Buckley outlines the typical bildungsroman as a novel that focuses on the moral, psychological, and intellectual development of a main character who is almost always a child. A bildungsroman usually consists of four stages that characters must face on their path to maturity. In the first stage, the protagonist experiences an event that is usually a tragic loss or a sense of unhappiness which causes the character to leave the home and set on a journey. In the second stage, the character is almost always stuck in an unbending social order where society has strict rules that one is supposed to follow. In the third stage, character struggles between his or her personal needs and the judgments enforced by the unbending social order. In the forth stage, the character finally learns how to evaluate the world and his or her place in society. The outcome of the novel is usually positive. After making some mistakes and experiencing painful disappointments, the character is able to move on and face a happy future. "By the time he has decided, after painful soul-searching, the sort of accommodation to the modern world he can honestly make, he has left his adolescence behind and entered upon his maturity” (Buckley, 1974, pp. 17-18).

In the Hunger Games trilogy, readers can find the four stages Katniss faces on her path to maturity. In the first novel of the Hunger Games trilogy, in order to protect her sister and her family, 16-year-old Katniss steps forward to take her sister's place in the Games, an event which is regarded as death sentence. As a "tribute" in the Games, Katniss sets on the journey of life and death and experiences the conflicting emotions of making choices that weigh survival against humanity and life against love:

I'm relieved Peeta's alive. I tell myself again that if I get killed, his winning will benefit my mother and Prim the most. This is what I tell myself to explain the conflicting emotions that arise when I think of Peeta. The gratitude that he gave me an edge by professing his love for me in the interview. The anger at his superiority on the roof. The dread that we may come face-to-face at any moment in this arena. (Collins, 2008, p. 157)

The iron rule of the Capitol is powerful and the Games are brutal. In order to survive, Katniss struggles between her personal needs of survival and the tyrannic ruling of the Capitol. Her bow and arrow is her weapon. Throughout the trilogy, Katniss uses her bow and arrow three times to show her defiance against the tyrannic ruling. The first time is when Katniss exhibits her excellent skills in handling bow and arrow in the center of the gymnasium before the Gamemakers:

It's excellent shooting. I turn to the Gamemakes. A few are holding approval, but the majority of them are fixated on a roast pig that has just arrived at their banquet table.

Suddenly I am furious, that with my on the line, they don't even have the decency to pay attention to me. That I'm being upstaged by a dead pig. My heart starts to pound. I can feel my face burning. Without thinking, I pull an arrow from my quiver and send it straight at the Gamemakers' table. I hear shouts of alarm as people stumble back. The arrow skewers the apple in the pig's mouth and pins it to the wall behind it. Everyone stares at me in disbelief.

“Thank you for your consideration”, I say. Then I give a slight bow and walk straight toward the exit without being dismissed. (Collins, 2008, pp. 181-182)

The arrow that Katniss shoots to the Gamemakers actually is an expression of her anger towards the unfair and inhuman treatment from the Capitol. It is also a signal of her struggle against evil. 
In Catch Fire, the second novel of the trilogy, Katniss shoots her second arrow against her enemy with her own life in danger:

My bow drops at his meaning registers. Yes, I know who the enemy is. And it’s not Enobaria.

I finally see Beetee's knife with clear eyes. My shaking hands slide the wire from the hilt, wind it around the arrow just above the feathers, and secure it with a knot picked up in training.

I rise, turning to the force field, fully revealing myself but no longer caring. Only caring about where I should direct my tip, where Beetee would have driven the knife if he'd been able to choose. My bow tilts up at the wavering square, the flaw, the... What did he call it that day? The chink in the armor. I let the arrow fly, see it hit its mark and vanish, pulling the thread of gold behind it.

My hair stands on end and the lightning strikes the tree. (Collins, 2009, p. 378)

With the shoot of the arrow, the dome of the force field bursts into a dazzling blue light and triggers explosion after explosion. Katniss' arrow totally destroys the arena designed by the Gamemakers. The second shoot of arrow symbolizes Katniss' turn from a naive girl to a brave fighter against tyranny.

In Mockingjay, the third novel of the trilogy, Katniss shoots her third arrow which bring the tyranny to the end. Through the third arrow, Katniss shows that she is no longer a piece in any Game, no matter it is a Hunger Game or a political game:

I feel the bow purring in my hand. Reach back and grasp the arrow. Position it, aim at the rose, but watch his face. He coughs and a bloody dribble runs down his chin. His tongue flicks over his puffy lips. I search his eyes for the slightest sign of anything, fear, remorse, anger. But there's only the same look of amusement that ended our last conversation. It's as if he’s speaking the words again. “Oh, my dear Miss Everdeen. I though we had agreed not to lie to each other".

He’s right. We did.

The point of my arrow shifts upward. I release the string. And President Coin collapse over the side of the balcony and plunges to the ground. Dead. (Collins, 2010, p. 372)

Through the brutal test of death and life, Katniss undergoes the stages of setting off on a journey, confusion and struggle between personal needs and social demands. At the end of the story, Katniss comes to a better understanding of self and the world and holds a positive view of the life and future, which indicates her final maturity:

Peeta and I grow back together. There are still moments when he clutches the back of a chair and hangs on until the flashbacks are over. I wake screaming from nightmares of mutts and lost children. But his arms are there to comfort me. And eventually his lips. On the night I feel that thing again, the hunger that overtook me on the beach, I know this would have happened anyway. That what I need to survive is not Gale's fire, kindled with rage and hatred. I have plenty of fire of myself. What I need is the dandelion i the spring. The bright yellow that means rebirth instead of destruction. The promise that life can go on, no matter how bad our losses. That it can be good again. (Collins, 2010, p. 388)

\section{Conclusion}

From the above analysis, the present paper argues that the success of the Hunger Games trilogy to the young readers is its distinctive blending of science fiction elements with protagonist Katniss' initiation. The trilogy suffice youth's interest to embrace a fiction that dramatizes both realistic and fantastic portray of the world. Through depicting the intellectual and social development of protagonist Katniss who, after experiencing both defeats and triumphs in a dystopian world, Suzanne Collins successfully conveys the coming-of-age theme under the veil of science fiction in the Hunger Games trilogy. 


\section{References}

Buckley, J. H. (1974). Season of youth: The bildungsroman from Dickens to Golding. Cambridge: Harvard University Press. Collins, S. (2008). The hunger games. New York: Scholastic Press.

Collins, S. (2009). Catching fire. New York: Scholastic Press.

Collins, S. (2010). Mockingjay. New York: Scholastic Press.

Connors, S. P. (2014). The subjugation of nature and women in The Hunger Games. In S. P. Connors (Ed.), The politics of Panem. Rotterdam: Sense Publishers.

DeaVault, R. M. (2012). The masks of femininity: Perceptions of the feminine in The Hunger Games and Podkayne of Mars. In M. F. Pharr and L. A. Clark (Eds.), Of bread, blood and the hunger games: Critical essays on the Suzanne Collins Trilogy. Jefferson: McFarland and Company.

Hubler, A. E. (2014). Lois Lowry’s and Suzanne Collins' dystopian fiction: Utopia and anti-utopia. Against the Current, 29 (3), 23. Sprague, M. (2016). Surviving dystopia: Lessons from Tally, Katniss and Tris. The Virginia English Journal, 65(2), 23-24. 